\title{
Production of Transgenic Cavendish Banana (Musa Acuminata L.) Resistant to Fungal Infection using Chitosan Nanoparticles
}

A.A.Hamed ${ }^{1}$, E.Tawfik ${ }^{2}$, A.B.Abdel-Razik ${ }^{3}$, M.A.Rashed ${ }^{3}$, S.H.Abdel-Aziz ${ }^{1}$ and M.A. El-Shafie ${ }^{1}$

${ }^{1}$ Botany and Microbiology Dept., Faculty of Science, Benha Univ., Egypt

${ }^{2}$ Botany and Microbiology Dept., Faculty of Science, Helwan Univ., Egypt

${ }^{3}$ Genetic Dept., Faculty of Agriculture, Ain Shams Univ., Egypt

E-Mail: amanyade1021@gmail.com

\begin{abstract}
Cavendish bananas 'Grand Nain' are commercially important cultivars. It belongs to the Cavendish subgroup of the AAA banana cultivar group. These cultivars face the problem of quick rotting due to infection with different phytopathogens. Gene transformation technique was used to improve the cultivar productivity and resistance to infection. Thionin genes (AT1G12660 and AT1G12663) were isolated from Arabidopsis thaliana. Thionin genes (thio-60 and thio-63) are antimicrobial genes producing antimicrobial proteins which inhibit fungal infection. These two thionin genes were integrated into the pEGAD vector. Then transformed into the tested banana cultivar via chitosan nanoparticles using the shoot tip culture technique. The chitosan nanoparticles are efficient, rapid and safe transformation technique. The resulted transgenic banana lines were partially resistant to infection by two different fungal species: Fusarium solani and Fusarium equiseti. These fungi cause rotting for the non-transgenic lines compared to the transgenic lines which resist the rotting infection due to the expressed inhibitory thionin protein. Transformation of thionin into the transgenic plants were confirmed by conventional PCR.
\end{abstract}

Keywords: Chitosan, Fusarium species, Musa acuminata, Thionin genes, Tissue culture, Transformation.

\section{Introduction}

Banana (Musa acuminata L.) belongs to Musa genus of the family Musaceae, is a popular fruit around the world and most important on both economic and social level. It is cultivated in temperate and subtropical regions over the world [1]. In Africa and in Egypt Banana is a good and valuable food crop, due to its major economic importance, nutritional quality and high availability. Recently propagating banana using tissue culture techniques increased rapidly, as it is believed to be the only recognized method to get rid of viral diseases and one of the most important modern breeding methods for a large number of vegetables and fruit crops globally. In Egypt, the multiplication of banana was carried out using tissue culture, which is accompanied by a great increase in the production quantity of the food crop [2]. As banana is one of the main fruit crops among Egypt's agricultural exports, it is important to enhance the production of banana with good desirable traits. Banana production all over the world is under continuous attacks by various pests and diseases. Banana plants are subjected to various pathogens and insect pests which cause considerable loss in quantitative and qualitative production. In order to meet the demands of international markets, banana plantations require large amounts of chemical fertilizers that translate into high farming costs and are hazardous to the environment when used excessively [3]. Therefore, novel strategies were developed to provide resistance against pathogens. The use of genetic engineering techniques is the most useful strategy to make genetic improvements by the integration of resistance genes derived from other organisms to produce transgenic plants resistant to many diseases [4-6].

Plant tissue culture technique is widely used to produce clones of a plant in a method known as micropropagation in which rapid proliferation is carried out successfully and considered as an important technique in commercial applications [7]. The process of micropropagation or clonal propagation is a complicated process which can be subdivided into several stages; pre-propagation, preparation of explants, the subculture of explants for proliferation, shooting and rooting, and hardening [8].

This study is concerned with a number of phytopathogenic Fusarium species which are hyaline filamentous fungi. They belongs to the family Nectriaceae of the order Hypocreales within the fungal phylum Ascomycota [9]. They are among the most destructive plant pathogenic and mycotoxigenic fungi which cause rotting and vascular wilts in numerous agricultural crops [10]. Fusarium species are very important pathogens of banana, especially causing such serious diseases as Panama disease and crown rot disease. [11] provides information regarding the diversity of Fusarium species associated with fruit rot of banana and discovered microfungi that belong to the genus Fusarium; Forty-eight isolates of the microfungi have been identified belonging to 11 species of Fusarium, including Fusarium equiseti (single isolate) and Fusarium solani (three isolates). Endophytic fungal species identified from Fusarium species occurring on banana leaves were Fusarium equiseti. Fusarium is among the fungal genera that have been reported as an endophyte of many plants and several endophytic Fusarium sPP. have been reported to be associated with banana plants. One 
isolate of Fusarium identified as $F$. equiseti was recovered from banana leaves. $F$. equiseti is a saprophyte or secondary colonizer of the disease plant part. Therefore, endophytic $F$. equiseti resides in banana leaves could later become saprophytes or secondary colonizers as the leaves aged [12].

Plants are subjected to many pathogenic microbes and their survival depends on the formation of peptides and proteins with antimicrobial properties that will play a role in defense mechanism. Thionins are major form of antimicrobial peptides in plants that used to produce resistant lines to plants diseases [13, 14]. Thionins are low-molecular-weight protein $(5 \mathrm{kDa})$, most of which occurring in seeds of higher plants but some thionins occur in stems, roots, or leaves. They are cysteine-rich proteins and had antimicrobial activity and toxic to different pathogens in vitro (antifungal properties). Thionins have $\mathrm{N}$-and $\mathrm{C}$-terminal amino acid sequences that are highly conservative but their nucleotide sequences are different $[15,16]$. The mechanism of thionins used by the plant to inhibit pathogenic fungi diseases was elucidated as follows: the antimicrobial properties of thionins are derived from their ability to induce pore formation on cell membranes of phytopathogens, causing a disturbance of the potassium and calcium ions balance and released from the cell [14].

Chitosan nanoparticle is useful as a non-viralmediated delivery vehicle for gene delivery that used for transformation. Chitosan nanoparticle is a polymer that is used in both gene therapy (nucleic acid delivery) and applications of tissue engineering [17]. Nanoparticles are used for transformation of both monocot and dicot plants and any organs types, it is a type of gene vectors that is able to overcome transgenic silencing by controlling the copies of DNA binding to nanoparticles effectively, nanoparticles can be easily functionalized to promote transformation process efficiency [18]. The cationic nature of chitosan allows for electrostatic interaction with other negatively charged molecules such as DNA, this property differentiates chitosan from other polysaccharides that usually may be either neutral or negatively charged in an acidic medium $[19,20]$.

The purpose of this study is to introduce transgenic banana lines resistant to fungal pathogens by expressing two antifungals Thionin genes (Thio60 and Thio63). The transformation protocol was by chitosan nanoparticles. We confirm that the thionin gene can transfer into the transgenic banana cultivars, and then tested the resistance of transgenic plants with the fungal pathogen Fusarium solani and Fusarium equiseti.

\section{Materials and methods 2.1 Plant material}

Banana Grand Nain cultivar (Musa acuminata) was used as a transgenic model. It was brought from Vitro plant Egypt and regenerated on MS media according to [21].

\subsubsection{Multiplication of explants}

The shoot tips were transferred in a jar containing $3 / 4$ MS media and sub-cultured every four weeks up to five times. The first and second subcultures have the same number of phytohormones $(\mathrm{BAP}=5 \mathrm{ml}, \mathrm{Kin}=1 \mathrm{ml})$. The third and fourth subcultures have the same number of phytohormones $(\mathrm{BAP}=4 \mathrm{ml}, \mathrm{Kin}=2 \mathrm{ml})$. The fifth subculture (pre-root) supplemented with phytohormones $(\mathrm{BAP}=1 \mathrm{ml}, \mathrm{Kin}=3 \mathrm{ml})$. These jars were incubaed in a growth chamber at $25^{\circ} \mathrm{C}$ (16hour light and 8-hour night).

\subsection{Thionin genes from Arabidopsis thaliana 2.2.1 Thionin genes}

Thionin genes (AT1G12660 " Thio-60" and AT1G12663 “"Thio-63 ”) were isolated from Arabidopsis thaliana and they were ligated to pEGAD vector then transformed into competent $E$. coli (DH5 $\alpha$ ) for amplification. After that, the amplified plasmid was isolated with each gene of interest [22].

\subsection{Bacterial strain and plasmid}

The cultures of E. coli (CD3 -389) containing pEGAD kindly provided from Agricultural Center for Genetic Engineering and Biotechnology (ACGEB) were grown for $24 \mathrm{~h}$ at $37^{\circ} \mathrm{Con} \mathrm{LB}$ agar plates with the appropriate antibiotic for plasmid $(50 \mu \mathrm{g} / \mathrm{ml}$ kanamycin). Then make LB broth media at $200 \mathrm{rpm}$ in order to isolate the vector (pEGAD) using alkaline lysis method following the protocol of [23].

\subsection{Digestion, Cloning and bacterial transformation}

Both the two thionin genes and the vector (pEGAD) were digested with the same restriction enzymes (EcoRI and HindIII) (Biolabs ®Inc) according to the manufacture protocol. The ligation process was performed between the pEGAD plasmid and both inserts (Thio-60 and Thio-63 genes) respectively at conditions $37^{\circ} \mathrm{C}$ for $2 \mathrm{hr}$. pEGAD vector carrying both Thio-60 and Thio-63 genes were transformed into chemically competent $E$. coli cells. The protocol of E. coli transformation according to $[22,24]$.

\subsection{Plasmid PCR}

The vector ( $\mathrm{pEGAD}$ ) containing each of thionin genes were isolated from DH5 CD3 -389 and a PCR reaction was established to confirm the cloning of the thionin genes inside the plasmid in the right direction $\left(5^{\prime}-3^{\prime}\right)$ using the primers specific to the vector (pEGAD) as follows: 
Forward: 5' ACCTGCCAACCAAAGCGAGAAC 3' and reverse: 5' TCAGGGTTATTGTCTCATGAGCG 3'. PCR reaction for plasmid PCR was performed for 40 cycles as follows: $1 \mathrm{~min}$ at $95^{\circ} \mathrm{C}, 1 \mathrm{~min}$ at $68^{\circ} \mathrm{C}$ and $1 \mathrm{~min}$ at $72^{\circ} \mathrm{C}$ [22].

\subsection{Chitosan nanoparticle transformation}

Chitosan nanoparticle was provided by the Agricultural Center for Genetic Engineering and Biotechnology, Faculty of Agriculture, Ain-Shams University (ACGEB).

\subsubsection{Preparation of chitosan-DNA nanoparticles (CS/pDNA)}

Chitosan (CS) was dissolved in $25 \mathrm{mM}$ acetic acid, then adjusted to $\mathrm{pH} 5.5$ at a final concentration of $1 \%$ (stock solution). It was found that $0.08 \%$ is the best concentration of chitosan transformation according to [22]. The CS and the pEGAD were incubated in a water bath at $55^{\circ} \mathrm{C}$ for $15 \mathrm{~min}$, respectively. Then $\mathrm{CS}-\mathrm{DNA}$ complexes were prepared by adding this CS concentration to an equal volume of a pDNA solution $(310 \mu \mathrm{L})$ followed by immediately intense stirring on a vortex mixer for $1 \mathrm{~min}$ [25].

\subsubsection{Transformation of Chitosan/pDNA into plant tissue}

Explants were cut from the three-week-old Musa acuminata cultivar plantlets. Then immersed in $(310 \mu \mathrm{l})$ of CS/pDNA for few seconds and transfer these segments without washing into $3 / 4 \mathrm{MS}$ medium containing hormones $(1 \mathrm{ml} / \mathrm{l} \mathrm{BAP}$ and $1 \mathrm{ml} / \mathrm{l} \mathrm{kin}$ ) and $100 \mu \mathrm{l} / \mathrm{l}$ ampicillin then incubated at $25 \pm 1{ }^{\circ} \mathrm{C}$ for 4 weeks to regenerate plants [22]. Some of the produced transgenic banana cultivars were used for gene analysis and the others were transferred into MS media containing rooting growth hormones $(1 \mathrm{ml} / \mathrm{l} \mathrm{NAA}, 1 \mathrm{ml} / \mathrm{l}$ IBA and $3 \mathrm{ml} / \mathrm{l} \mathrm{kin})$ and incubated at $25^{\circ} \mathrm{C}$ under light conditions (16h light and $8 \mathrm{~h}$ dark for 4 weeks).

\subsection{Acclimatization stage}

Young plantlets arising from in vitro culture (transgenic and non-transgenic) were washed with running tap water to get rid of the medium remains then cultured in plastic pots filled with a mixture of peat moss: perlite $(2: 1 \mathrm{v} / \mathrm{v})$ and irrigated with water only. Finally, plantlets were kept inside a plastic tunnel for the duration of the acclimatization stage (six weeks).

\subsection{Molecular analysis of transgenic plants \\ 2.8.1 PCR analysis}

Genomic DNA from ampicillin resistant and control banana plants 4-5 weeks old were extracted using a modified cetyl trimethyl ammonium bromide (CTAB) method [26]. PCR was performed using genomic DNA as a target and primers as follows: $\quad$ forward 60 , 5'ATGGAGGACAAAAGAGTG3'; reverse 60, 5'TCATAGACTAAAATCAATAGC3'; forward 63, 5'ATGTTGGTGGCAGTAATGAT3'; and reverse 63, 5'CTAGTTTTTCTTGGTACACTT3'. PCR amplification reactions consisted of an initial denaturation at $95^{\circ} \mathrm{C}$ for $3 \mathrm{~min}$ followed by 40 cycles of denaturation at $95^{\circ} \mathrm{C}$ for $1 \mathrm{~min}$, annealing at $54{ }^{\circ} \mathrm{C}$ for $1 \mathrm{~min}$, extension at $72{ }^{\circ} \mathrm{C}$ for $1 \mathrm{~min}$ and a post-extension at $72{ }^{\circ} \mathrm{C}$ for $10 \mathrm{~min}$. Taq DNA polymerase was used in all PCR reactions. The resulting PCR products were separated by electrophoresis agarose gel $0.8 \%$ conc.

\subsubsection{DNA agarose gel electrophoresis}

Electrophoresis of DNA was carried out in horizontal agarose gels submerged in 1x Tris borate EDTA (TBE) running buffer. The gel of $0.8 \%$ concentration was prepared by dissolving of $0.8 \mathrm{~g}$ of agarose into $100 \mathrm{ml}$ of $1 \mathrm{X}$ TBE buffer according to [23]. Ethidium bromide to a final concentration of $10 \mu \mathrm{g} / \mathrm{mL}$ was added to the gel buffer. DNA samples were prepared and the samples with an appropriate DNA ladder were loaded onto the gel and electrophoresed at $100 \mathrm{~V}$ until the bromophenol blue dye migrated two thirds the length of the gel. DNA bands were detected by the orange fluorescence of the ethidium bromide DNA complex under UV light illumination at $254 \mathrm{~nm}$ wavelength. Gels were photographed using a Gel Documentation system.

\subsection{Fungal-resistance assay of transgenic plants}

This test was applied to test fungal resistance of transgenic banana cultivars expressing thionin against the phytopathogenic fungi. Two different fungal pathogens were applied to the transgenes of the banana cultivar. These pathogenic fungi were: Fusarium solani (Mart.) Sacc. and Fusarium equiseti (Corda.) Sacc. The infection method was as follows: Fungi grow on potato dextrose agar (PDA) until the surface of the agar in the Petri dish was covered with the fungal mycelia. For inoculation, a block of the agar (with grown mycelia) was placed near to the base of in vitro transgenic and nontransformed control plants (2 weeks old) grown on $100 \mathrm{ml} \mathrm{MS}$ medium and incubated at $25^{\circ} \mathrm{C}$ with $16 \mathrm{~h}$ light/ $8 \mathrm{~h}$ dark regime. Pictures were taken 2 weeks after incubation [27, 28].

\section{Results}

\subsection{Plant material and growth conditions}

In the present study, shoot tip cultures of the banana cultivar (Musa acuminata) were derived from shoot apices as explant sources which were found to be the best explants for shoot induction on MS media and most common practice for in vitro plant regeneration of banana and plantain. This agreed with [29] who explored the in vitro propagation techniques by using shoot tip 
cultures of banana as the possibilities to overcome the low number of shoots produce per explant obtained through conventional methods (suckers) that don't meet the increasing demand for planting and they are of poor quality. The regeneration of these plants continued for six months to keep them until transforming the thionin genes carried out. The shape of banana cultivars after growth on MS media are shown in the Fig (1a).

\subsection{Transformation of banana with thionin genes (thio60 and thio63) by chitosan nanoparticles}

Chitosan nanoparticle transfection method was used in this study to transfer the thio60 and thio63 vectors into banana cultivars. CS/pDNA was successfully prepared with defined conditions and used as an effective gene delivery system. This agreed with [30, 31] also [22] confirmed the use of chitosan nanoparticles as a carrier of thionin genes through transformation into potato plants.
In this experiment, $\mathrm{CS}$ was investigated as potential delivery systems for pDNA in vitro. Shoot tips were immersed in CS/pDNA mix $(0.08 \% \mathrm{CS}$ is the best concentration of chitosan transformation) for few seconds then transferred into MS media with $100 \mu \mathrm{g} / \mathrm{ml}$ ampicillin and growth hormones ( $1 \mathrm{ml} / \mathrm{l} \mathrm{BAP}$ and $2 \mathrm{ml} / \mathrm{l} \mathrm{kin})$. After 4 -weeks of incubation at $25^{\circ} \mathrm{C}$ under light conditions, the shoots are fully grown and multiplied. Then part of them was tested for gene transfer where the others were transferred into rooting MS media. The transformed banana with Thio60 and Thio63 genes via $\mathrm{CS}$ as shown in the fig. $(1 \mathrm{~b}, \mathrm{c})$. Similar results were obtained by [22] who used chitosan nanoparticle as a carrier of pEGAD containing thionin genes through transformation into potato (Solanum tuberosum L.) plant. Also agreed with [32] who used chitosan nanoparticle as a carrier of pBDG containing GFP gene through transformation into Paulownia sp and Echinacea purpurea plant.

\subsubsection{CS/pDNA transfection into plant tissue}
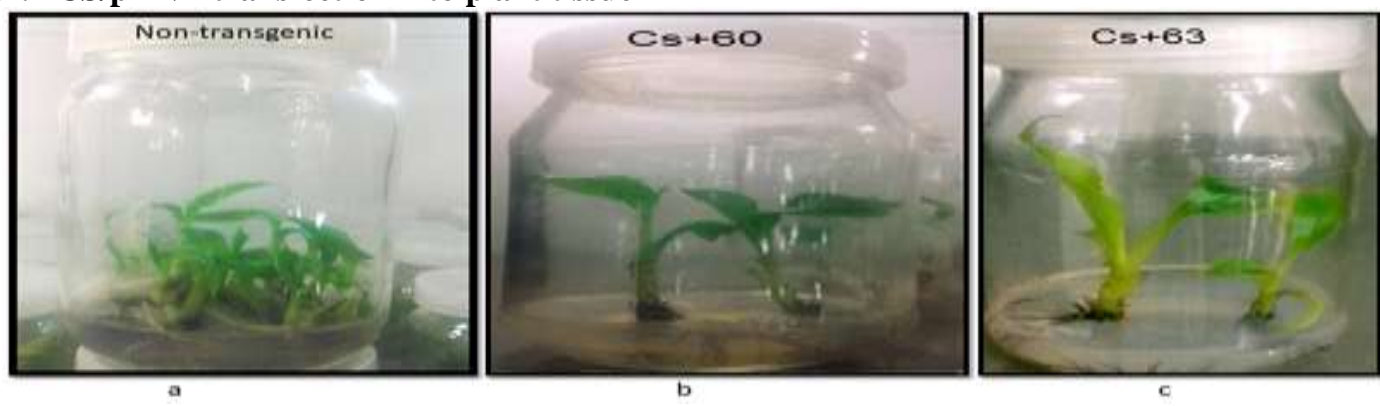

Fig (1) Banana on MS media after 5 weeks culture. (a) non-transgenic, (b) transgenic with thio-60, and (c) transgenic with thion-63.

\subsection{Molecular analysis of the transgenic plant}

The integration of transgenes thio60 and thio63 into banana tissue is detected and confirmed by PCR analysis by selecting the ampicillin resistant clones of modified plasmid as described in [33] who applied PCR to confirm the presence of the Sm-AMP-Dl gene into transformed banana plant; and [34] who confirmed the presence of the Hrap gene in randomly selected kanamycin-resistant banana lines using PCR with specific primers. No amplified band was shown in PCR products from the total DNA of non-transformed control banana cultivars as a negative control for transformation as shown in the fig (2).

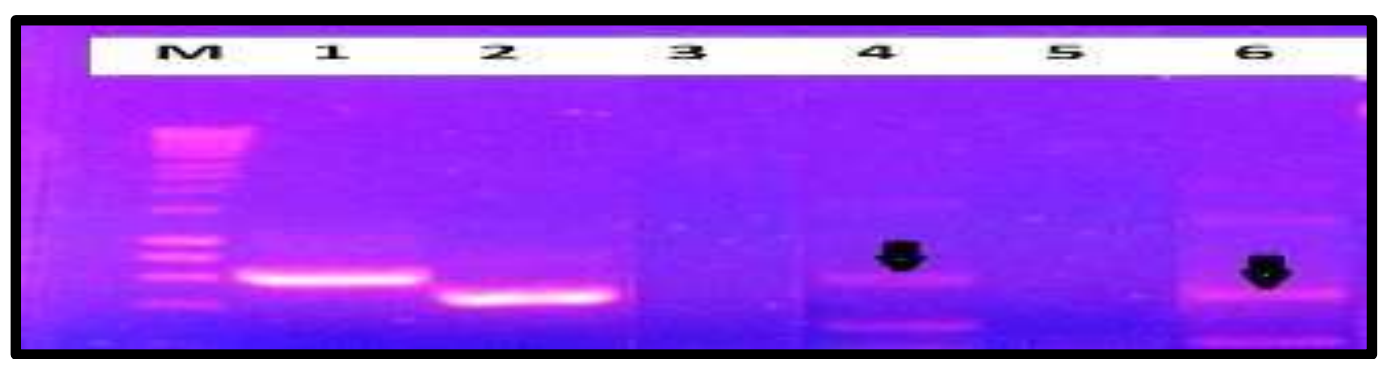

Fig (2) Gel electrophoresis of the PCR products of thionin genes within the Control banana cultivar (non-transformed) and transformed banana cultivars. M: hyper ladder $1 \mathrm{~kb}$ (Bioline, Cat\#BIO-33053); (1): Thio-60 from Arabidopsis thaliana (641 bp); (2): Thio-63 from Arabidopsis thaliana (489 bp); (3): Thio-60 from non-transgenic banana (not detected); (4): Thio-60 from transgenic banana; (5): Thio-63 from non-transgenic banana (not detected); 6: Thio-63 from transgenic banana.

\subsection{Acclimatization stage}

Young plantlets arising from in vitro culture (transgenic and non-transgenic) were cultured in 
plastic pots filled with a mixture of peat moss: perlite $(2: 1 \mathrm{v} / \mathrm{v})$ and irrigated with water only. The duration of the acclimatization stage continued for six weeks. Fig (3) showed the non-transformed banana cultivar (control) and transformed banana lines with thio60 and thio63 genes via Cs after hardening.

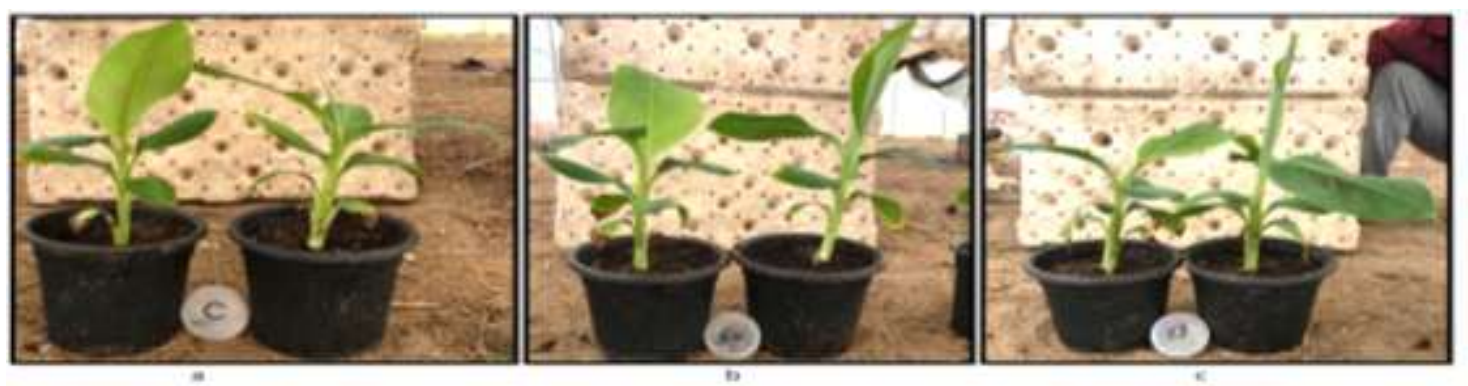

Fig (3) The non-transformed banana cultivar (control) and transformed banana lines with thio60 and thio63 genes via Cs after hardening. (a) Non-transgenic banana cultivar (control), (b) transgenic banana cultivar with Thio60, and (c) transgenic banana cultivar with Thio63.

\subsection{Pathogenicity test}

Fungal resistance of transgenic banana plants expressing thionin genes was evaluated against the phytopathogenic fungi: Fusarium solani and Fusarium equiseti. This cope with [35] who proved that thionins inhibit the growth in vitro of about 20 different fungal plant pathogens including Fusarium sPP. As thionins are known to form cation-selective ion channels by binding to phosphatidylserine head groups in lipid bilayer membranes which cause permeabilization and oxidative burst followed by cell death in target cells
[36-38]. Also [14] explained that the antibacterial and antifungal properties of thionins are derived from their ability to induce pore formation on cell membranes of phytopathogens, resulting in the release of potassium and calcium ions from the cell. Transgenic banana cultivars with thio-60 and thio63 showed high resistance against phytopathogenic fungi compared to non-transgenic banana cultivars. In vitro symptoms of both transgenic and nontransgenic banana cultivars with two pathogenic fungi ( $F$. solani and $F$. equiseti) are shown in fig (4).

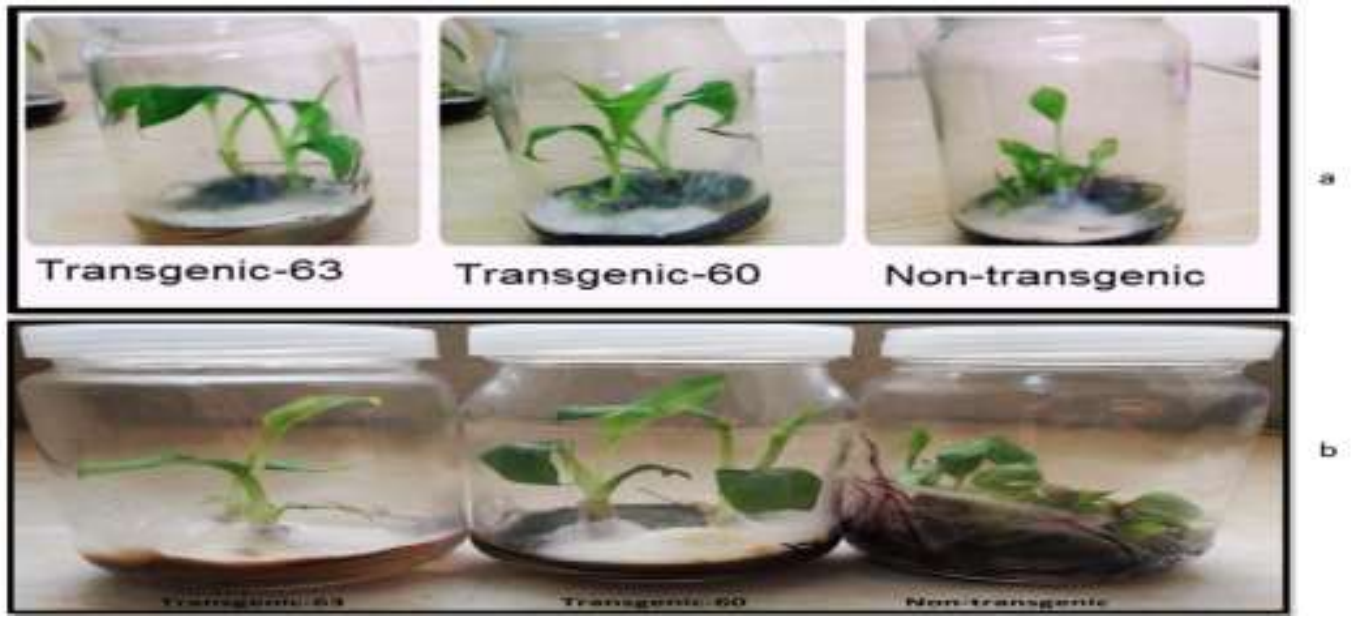

Fig (4) The diseases symptoms on both transgenic and non-transgenic banana cultivars. (a)

F. solani, (b) F. equiseti.

In conculosions, chitosan nanoparticle transformation is an efficient, rapid and safe technique for genetic transformation. Thionin genes are antimicrobial genes producing antimicrobial inhibitory peptides for phytopathogenic Fusarium sPP. The resulted transgenic banana lines are partially resistant to different Fusarium infection.

\section{Acknowledgments}

The corresponding author gratefully acknowledges Mr. Mohamed Fathy (MSc, Tissue Culture laboratory, Agricultural Center for Genetic Engineering and Biotechnology "ACGEB", Faculty of Agriculture, Ain Shams University) for his effort in this work in the part of tissue culture of the banana plant. 


\section{References}

[1]S. Rahman, N. Biswas, M.M. Hassan, M.G. Ahmed, A. Mamun, M.R. Islam, M. Moniruzzaman, and M.E.J.I.R.J.B. Haque, Micropropagation of banana (Musa sp.) $c v$. Agnishwar by in vitro shoot tip culture, Vol.4, PP. 83-88, 2013.

[2] S.A. Abdelmajeed, and M. Aboul-Nasr, Financial feasibility study of bananas tissue culture commercial production in Egypt. Journal of Finance, Accounting and Management, Vol.4, PP. 87, 2013.

[3] R.M. Gamez, F. Rodríguez, N.M. Vidal, S. Ramirez, R. Vera Alvarez, D. Landsman, and L. Mariño-Ramírez, Banana (Musa acuminata) transcriptome profiling in response to rhizobacteria: Bacillus amyloliquefaciens Bs006 and Pseudomonas fluorescens Ps006. BMC Genomics, Vol.20, PP. 378, 2019.

[4] L. Tripathi, H. Atkinson, H. Roderick, J. Kubiriba, J.N.J.F. Tripathi, and e. security, Genetically engineered bananas resistant to Xanthomonas wilt disease and nematodes, Vol.6, PP. 37-47, 2017.

[5] V. Swarupa, K. Ravishankar, and A. Rekha, Plant defense response against Fusarium oxysporum and strategies to develop tolerant genotypes in banana. Planta, Vol.239, PP. 735$751,2014$.

[6] P. Kant, Y. Reinprecht, C. Martin, R. Islam, and K. Pauls, $4.59 \quad$ Disease Resistance/Pathology/Fusarium. 2011.

[7] A.V. Gaikwad, S. Singh, and R. Gilhotra, Plant tissue culture-A review. J. Pharm. Res. Educ, Vol.2, PP. 217-220, 2017.

[8] H.A. Bhoite, and G.S. Palshikar, Plant tissue culture: A review. World journal of pharmaceutical sciences, Vol.2, PP. 565-572, 2014.

[9] A.M. Al-Hatmi, J.F. Meis, and G.S. de Hoog, Fusarium: molecular diversity and intrinsic drug resistance. PLoS pathogens, Vol.12, PP. e1005464, 2016.

[10] K. O’Donnell, A.P. Rooney, R.H. Proctor, D.W. Brown, S.P. McCormick, T.J. Ward, R.J. Frandsen, E. Lysøe, S.A. Rehner, and T. Aoki, Phylogenetic analyses of RPB1 and RPB2 support a middle Cretaceous origin for a clade comprising all agriculturally and medically important fusaria. Fungal Genetics and Biology, Vol.52, PP. 20-31, 2013.

[11] N. Abd Murad, N. Mohamed Nor, S. Shohaimi, and N. Mohd Zainudin, Genetic diversity and pathogenicity of Fusarium species associated with fruit rot disease in banana across Peninsular Malaysia. Journal of applied microbiology, Vol.123, PP. 1533-1546, 2017.

[12] L. Zakaria, and W.N.W. Aziz, Molecular Identification of Endophytic Fungi from Banana
Leaves (Musa sPP.). Tropical life sciences research, Vol.29, PP. 201, 2018.

[13] M.S. Castro, and W. Fontes, Plant defense and antimicrobial peptides. Protein and Peptide letters, Vol.12, PP. 11-16, 2005.

[14] T. Asano, A. Miwa, K. Maeda, M. Kimura, and T. Nishiuchi, The secreted antifungal protein thionin 2.4 in Arabidopsis thaliana suppresses the toxicity of a fungal fruit body lectin from Fusarium graminearum. PLoS pathogens, Vol.9, PP. e1003581, 2013.

[15] Z. Sadati, M. Ghanbari, V. Babaeizad, and H. Rahimian, Expression of Thionin and PDF1. 2 coding genes as antimicrobial polypeptides in interaction of rice against rice blast agent, Magnaporthe oryzae. Iranian Journal of Plant Pathology, Vol.50, 2014.

[16] K. Hoshikawa, G. Ishihara, H. Takahashi, and I. Nakamura, Enhanced resistance to gray mold (Botrytis cinerea) in transgenic potato plants expressing thionin genes isolated from Brassicaceae species. Plant Biotechnology, PP. 1203170075-1203170075, 2012.

[17] R. Raftery, F. O'Brien, and S.-A. Cryan, Chitosan for gene delivery and orthopedic tissue engineering applications. Molecules, Vol.18, PP. 5611-5647, 2013.

[18] Y.-Q. Fu, L.-H. Li, P.-W. Wang, J. Qu, Y.-P. Fu, H. Wang, and J.-R. Sun, Delivering DNA into plant cell by gene carriers of $\mathrm{ZnS}$ nanoparticles. CHEMICAL RESEARCH IN CHINESE UNIVERSITES, Vol.28, PP. 672676, 2012.

[19] J. Venkatesan, and S.-K. Kim, Chitosan composites for bone tissue engineering - an overview. Marine drugs, Vol.8, PP. 2252-2266, 2010.

[20] N.A. Mohamed, M.W. Sabaa, A.H. ElGhandour, M.M. Abdel-Aziz, and O.F. AbdelGawad, Quaternized N-substituted carboxymethyl chitosan derivatives as antimicrobial agents. International journal of biological macromolecules, Vol.60, PP. 156164, 2013.

[21] T. Murashige, and F. Skoog, A revised medium for rapid growth and bio assays with tobacco tissue cultures. Physiologia plantarum, Vol.15, PP. 473-497, 1962.

[22] A.B.Abdel-Razik, I.A.H., and E. Tawfik,, Transformation of Thionin Genes Using Chitosan Nanoparticle into Potato Plant to Be Resistant to Fungal Infection. . IOSR Journal of Biotechnology and Biochemistry, Vol.03, PP. 01-13, 2017.

[23] J. Sambrook, E.F.F., and T. Maniatis, Molecular cloning: a laboratory manual. Cold spring harbor laboratory press, 1989.

[24] M. Kavas, Development of salt resistant transgenic plants by using TANHX1 and TASTR genes. Thedegree of doctor of 
philosophy in biology, the graduate school of natural and applied sciences of middle east technical university,. 2011.

[25] S. Mansouri, Y. Cuie, F. Winnik, Q. Shi, P. Lavigne, M. Benderdour, E. Beaumont, and J.C. Fernandes, Characterization of folate-chitosanDNA nanoparticles for gene therapy. Biomaterials, Vol.27, PP. 2060-2065, 2006.

[26] S. Yadav, P. Sharma, A. Srivastava, P. Desai, and N. Shrivastava, Strain specific Agrobacterium-mediated genetic transformation of Bacopa monnieri. Journal of Genetic Engineering and Biotechnology, Vol.12, PP. 8994, 2014.

[27] R.S. Khan, R. Sjahril, I. Nakamura, and M. Mii, Production of transgenic potato exhibiting enhanced resistance to fungal infections and herbicide applications. Plant Biotechnology Reports, Vol.2, PP. 13-20, 2008.

[28] R.S. Khan, V.O. Ntui, D.P. Chin, I. Nakamura, and M. Mii, Production of marker-free diseaseresistant potato using isopentenyl transferase gene as a positive selection marker. Plant cell reports, Vol.30, PP. 587-597, 2011.

[29] M. Ngomuo, E. Mneney, and P.A. Ndakidemi, The in vitro propagation techniques for producing banana using shoot tip cultures. American Journal of Plant Sciences, Vol.5, 2014.

[30] K. Xing, X. Zhu, X. Peng, and S. Qin, Chitosan antimicrobial and eliciting properties for pest control in agriculture: a review. Agronomy for Sustainable Development, Vol.35, PP. 569-588, 2015.

[31] A. Bozkir, and O.M. Saka, Chitosan nanoparticles for plasmid DNA delivery: effect of chitosan molecular structure on formulation and release characteristics. Drug Delivery, Vol.11, PP. 107-112, 2004.

[32] HM. Nour El-Hoda, Evaluation of Nanoparticles Transfer of Bio-Control Related Gene
(S) Via Gene Expression,Department of Genetics, Faculty of Agriculture, Ain Shams University., 2017.

[33] A. Ghosh, T. Ganapathi, P. Nath, and V. Bapat, Establishment of embryogenic cell suspension cultures and Agrobacteriummediated transformation in an important Cavendish banana cv. Robusta (AAA). Plant Cell, Tissue and Organ Culture (PCTOC), Vol.97, PP. 131-139, 2009.

[34] L. Tripathi, H. Mwaka, J.N. Tripathi, and W.K. Tushemereirwe, Expression of sweet pepper Hrap gene in banana enhances resistance to Xanthomonas campestris pv. musacearum. Molecular Plant Pathology, Vol.11, PP. 721731, 2010.

[35] B. Cammue, M. De Bolle, F. Terras, P. Proost, J. Van Damme, S.B. Rees, J. Vanderleyden, and W.F. Broekaert, Isolation and characterization of a novel class of plant antimicrobial peptides form Mirabilis jalapa L. seeds. Journal of Biological Chemistry, Vol.267, PP. 2228-2233, 1992.

[36] P. Hughes, E. Dennis, M. Whitecross, D. Llewellyn, and P. Gage, The cytotoxic plant protein, $\beta$-purothionin, forms ion channels in lipid membranes. Journal of Biological Chemistry, Vol.275, PP. 823-827, 2000.

[37] B. Hilpert, H. Bohlmann, R.o. Den Camp, D. Przybyla, O. Miersch, A. Buchala, and K. Apel, Isolation and characterization of signal transduction mutants of Arabidopsis thaliana that constitutively activate the octadecanoid pathway and form necrotic microlesions. The Plant Journal, Vol.26, PP. 435-446, 2001.

[38] A. Coulon, E. Berkane, A.-M. Sautereau, K. Urech, P. Rougé, and A. Lopez, Modes of membrane interaction of a natural cysteine-rich peptide: viscotoxin A3. Biochimica et Biophysica Acta (BBA)-Biomembranes, Vol.1559, PP. 145-159, 2002. 